\title{
Article
}

\section{Determination of moisture resistance of covered electrodes according to PN-EN ISO 14372}

\author{
Katarzyna Mielnicka ${ }^{1}$, Adrian Wolski ${ }^{1}$, Aleksandra Świerczyńska ${ }^{1}$, Grzegorz Rogalski ${ }^{1}$, Dariusz Fydrych ${ }^{1, *}$ \\ ${ }^{1}$ Gdańsk University of Technology, Poland \\ Katarzyna Mielnicka, Eng., katmieln@student.pg.edu.pl; \\ Adrian Wolski, Eng., adrwolsk@student.pg.edu.pl; \\ Aleksandra Świerczyńska, Ph.D. Eng., aleswier@pg.edu.pl; \\ Grzegorz Rogalski, Ph.D., D.Sc., grzrogal@pg.edu.pl; \\ * Correspondence: Prof. Dariusz Fydrych, darfydry@pg.edu.pl
}

Received: 17.04.2019; Accepted: 02.07.2019

\begin{abstract}
Moisture present in the electrode covering is one of the sources of diffusible hydrogen in welded joints. In order to study the diffusible hydrogen content in deposited metal, a stand for moisturizing covered electrodes, in accordance with the PN-EN ISO 14372 standard, was built. After the stand was completed, a test of moisturizing the electrodes was carried out and measurements of the diffusible hydrogen content in deposited metal using the mercury method (according to PN-EN ISO 3690) were conducted. The research was aimed at verifying the correctness of the operation of test stand and indirect determination of the influence of storage of rutile-cellulose and cellulose electrodes under fixed conditions on the degree of moisturizing of the weld metal. Both tested electrode grades belong to the group of electrodes with a standard covering.
\end{abstract}

Keywords: diffusible hydrogen; resistance to moisture; covered electrodes

\section{Introduction}

The condition of filler materials used during welding is a factor that significantly affects the quality of

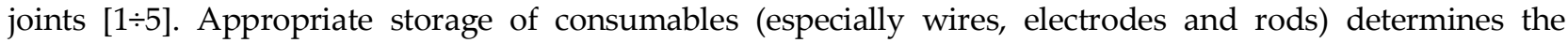
possibility of obtaining the highest joint properties: metallurgical purity, homogeneity and required strength [6:8]. Storage conditions should ensure that the influence of external factors on the suitability of the consumables for the process is minimized. Limiting this impact to a minimum is most often desirable because of the presence of hydrogen-containing compounds in the welding environment. This requires monitoring and

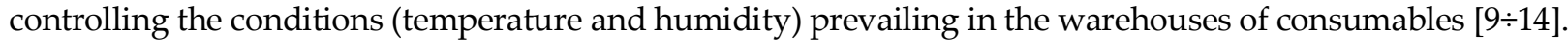

During welding both in the base material and in the environment many physical and chemical processes occur. High temperature intensifies the course of these reactions and phenomena, including the dissolution of hydrogen in metals. The presence of hydrogen during the welding process is one of the determinants of the formation of cold cracks and contributes to the formation of porosity. The main sources of this element during welding are: moisture, water vapor, organic components of the covering as well as hydrocarbons and other impurities. These sources are the potential hydrogen, which can hypothetically penetrate the joint and on which the amount of total hydrogen depends. Total hydrogen present in the joint can be divided into [11,13]:

- diffusible, having the ability to diffuse under normal conditions, responsible for the formation of cracks;

- residual, being a part of total hydrogen which under normal conditions remains trapped in hydrogen traps (in structure and incompatibilities).

Figure 1 shows a diagram illustrating the qualitative relationship between individual types of hydrogen in welded joints.

It is believed that residual hydrogen is not a threat to the quality of the joint, while diffusible hydrogen is dangerous from the point of view of the possibility of failure (resulting from the definition of weldability of steel) of the metallic continuity of the joint. Due to the small diameter of the atom, this element easily diffuses in dissolved metals, accumulating in material discontinuities or in non-metallic inclusions, even of the most compact crystal lattices. Its solubility and diffusion coefficient change with temperature changes and also depend on the structure and chemical composition of the metal (Fig. 2 and Fig. 3). Many hypotheses and models 
have been developed explaining the mechanisms of hydrogen embrittlement, but this issue is still not finally resolved [15:18].

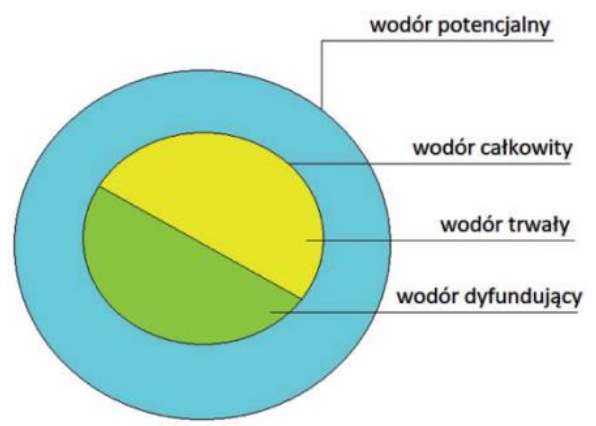

Fig. 1. Hydrogen fractions in welded joint

The hydrogen content in the weld metal is also influenced by technological factors of the process: welding method, heat input value, conditions occurring during making the joint (temperature and humidity of the environment), drying of filler materials, preheating and heat treatment after welding $[2,9,10]$. The process parameters are chosen so that the probability of hydrogen entering the joint is as low as possible.

Of the many methods for determination of diffusible hydrogen amount in the joint, the most commonly used methods are: mercury, glycerin and various variants of high temperature extraction $[11,13,19]$. The first of them, due to the lack of solubility of hydrogen in the research medium, is characterized by high accuracy and is a reference method for other research methods. The scope of application of the mercury method is limited due to the high toxicity of mercury. The information obtained in this way on the diffusible hydrogen content in the weld metal can be used not only to assess the propensity of steel to create cold cracks, but also to classify welding consumables and determine hydrogen sources. These results can also be used to calculate the minimum preheating temperature of joined elements [11].

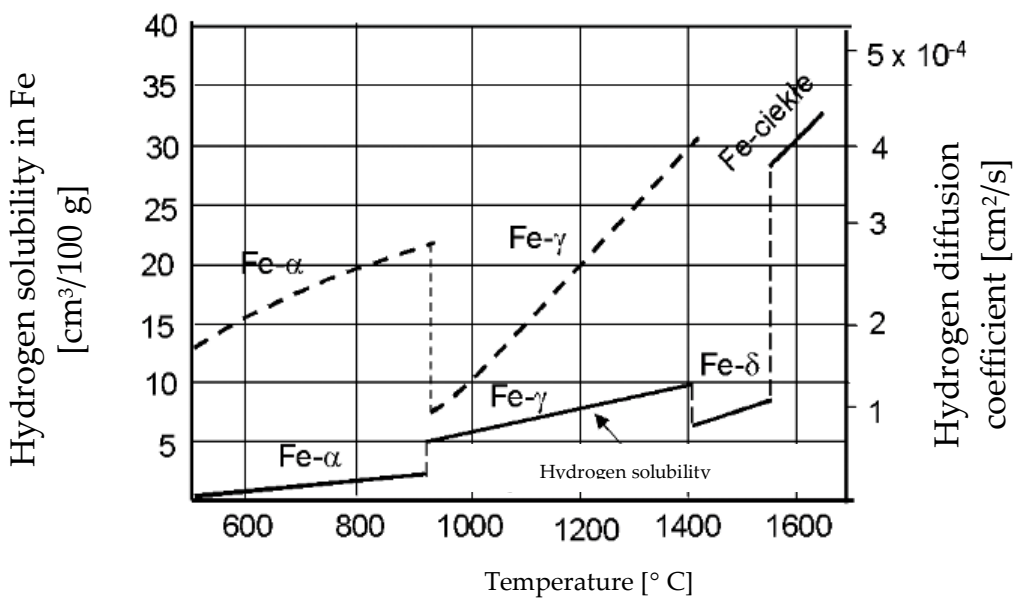

Fig. 2. Solubility of hydrogen in iron depending on temperature and pressure [20]

The criteria for classification of consumables for welding by methods 111, 136 and 138 include, among others content of diffusible hydrogen in deposited metal expressed on a linear scale: 5,10 and $15 \mathrm{ml} / 100 \mathrm{~g}$ (International Institute of Welding) or logarithmic: 4, 8 and $16 \mathrm{ml} / 100 \mathrm{~g}$ (American Welding Society) [21]. During arc welding, the filler material in the form of a covered electrode plays a fundamental role. Depending on the composition, structure and thickness, the covering may give the joint specific properties. The tasks of the covering also include: facilitation of ignition and stabilization of the welding arc, protection of molten metal against the harmful effects of external factors and slag production.

The hydrogen amount in deposited metal strongly depends on the type of covering. Basic covered electrodes belong to low-hydrogen filler materials (diffusible hydrogen content in deposited metal does not exceed $5 \mathrm{ml} / 100 \mathrm{~g}$ ), while cellulose and rutile electrodes generate much higher amounts of diffusible hydrogen $(30 \div 45 \mathrm{ml} / 100 \mathrm{~g})$. The high hydrogen content in the deposited metal of the latter is due to the presence of hydrogen compounds (water, cellulose and other organic compounds) in the cover components and its hygroscopicity. One method of limiting of diffusible hydrogen in deposited metal is drying of the electrodes. Low-hydrogen electrodes are dried in dryers at a temperature of $300 \div 350{ }^{\circ} \mathrm{C}$ for $1 \div 3$ hours, and then stored 
in heated thermoses. Rutile electrodes usually do not require drying, however, in some cases, manufacturers recommend performing this treatment at a temperature of $100 \div 150{ }^{\circ} \mathrm{C}$ for 1 to 2 hours. Cellulose covering provides the electrodes with the best welding properties when it contains about $3 \%$ water, therefore, electrodes of this type are not dried $[22 \div 25]$.

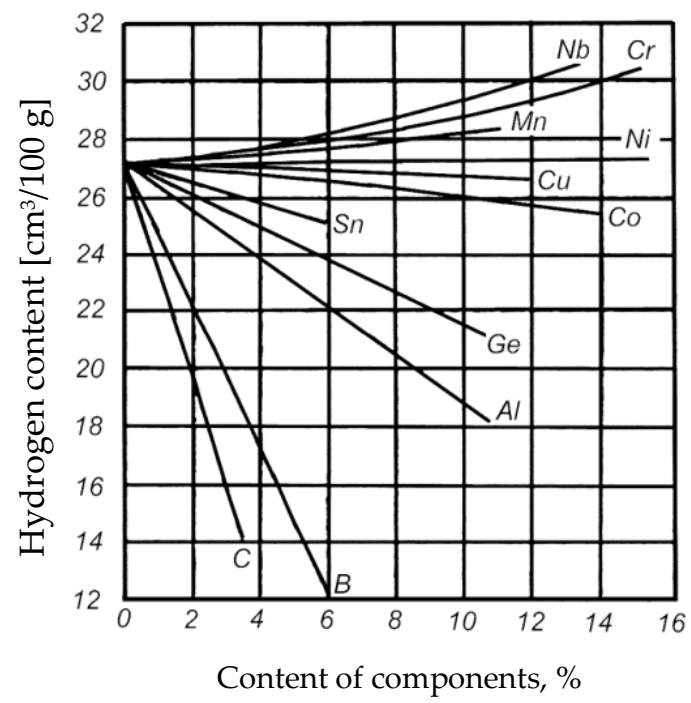

Fig. 3. Solubility of hydrogen at $1873 \mathrm{~K}$ and $\mathrm{pH} 2=0,102 \mathrm{MPa}$ in liquid iron alloys depending on the content of components [26]

Bearing in mind the sensitivity of covered electrodes to storage conditions and the need to assess their covering's moisture resistance, the article presents the design and construction of a covered electrode's moisturizing station according to PN-EN ISO 14372 "Welding consumables - Determination of moisture resistance of manual metal arc welding electrodes by measurement of diffusible hydrogen", as well as the principles of carrying out tests to assess the moisture resistance of electrodes by measuring of diffusible hydrogen amount in deposited metal and verifying the correct operation of the constructed test stand.

\section{Materials and research methodology}

The PN-EN ISO 14372 standard describes the construction of a test stand that allows testing the moisture resistance of covered electrodes under strict conditions $\left(27 \pm 1^{\circ} \mathrm{C}\right.$ in the presence of ammonium sulfate). The first element that is included in the test stand is the moisturizing container, shown in Figures 4 and 5. It is required that it is made of inert material (acrylic or similar). In this case, PMMA (polymethyl methacrylate) was used $[27,28]$. The container has three transversely arranged rungs on which covered electrodes are placed, protective glass tubes (internal diameter $\sim 1.5 \mathrm{x}$ larger than the external diameter of the electrodes, with a permanent and temporary plug) made of glass and a thermometer. This assembly is located over a saturated ammonium sulfate solution and is closed by a cover $[27,28]$.

Another element of the test stand is a temperature-controlled locker. A thermally insulated locker with internal dimensions of $625 \times 425 \times 300 \mathrm{~mm}$ made of EEP polypropylene foam was used as the casing $[27,28]$. Inside there are:

- a fan ensuring an even air circulation;

- light bulb being the source of heat;

- thermostat forcing the bulb to maintain a constant temperature of $27 \pm 1^{\circ} \mathrm{C}$;

- thermometer sensor with a display located outside the locker;

- moisturizing container.

The test stand and its connection are shown in figures 6 and 7.

The idea of assessing the moisture resistance of electrode coverings presented in the standard is based on the relationship between the amount of potential hydrogen and the diffusible hydrogen content and boils down to assessing the hygroscopicity of the covering by measuring of the diffusible hydrogen amount in deposited metal. This requires the storage of covered electrodes in an atmosphere of humid air $\left(27^{\circ} \mathrm{C}\right.$, $80 \% \mathrm{RH})$, followed by the determination of diffusible hydrogen amount by the mercury method. 

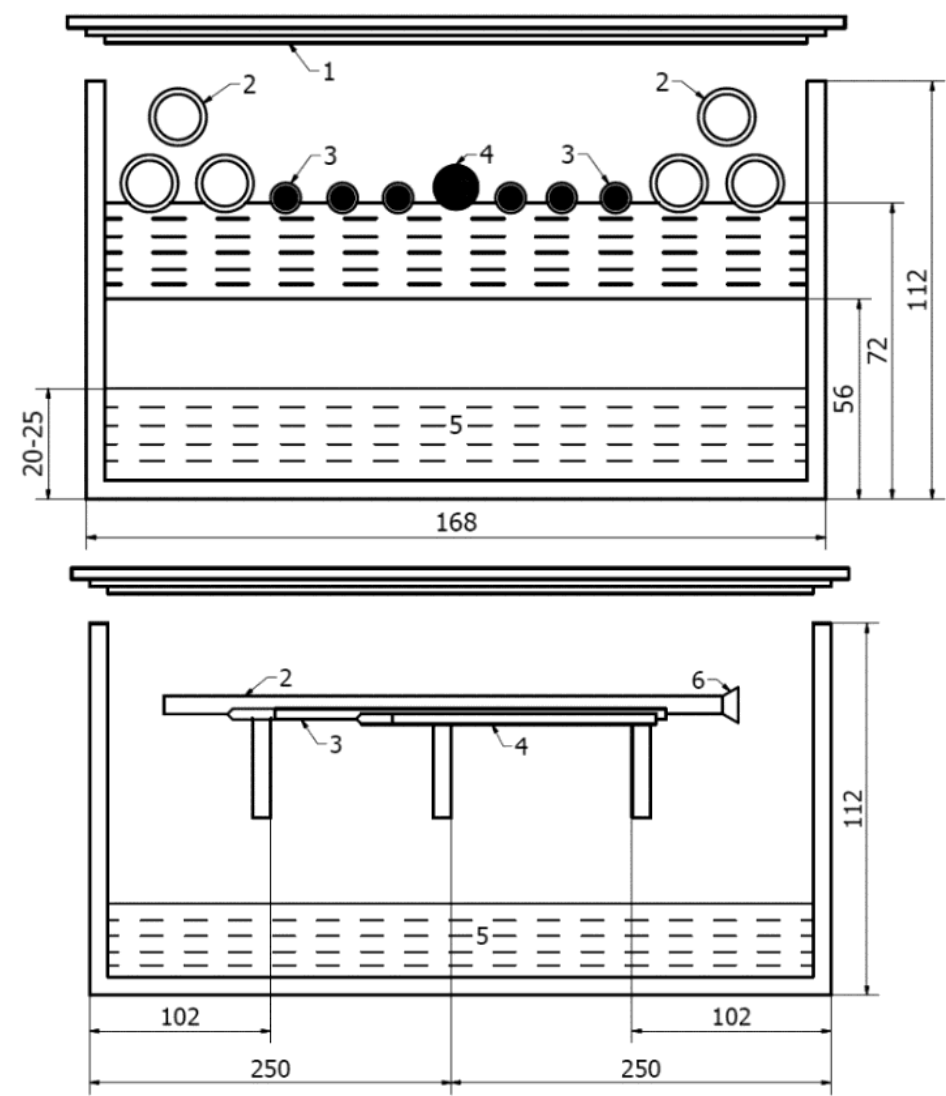

Fig 4. Scheme of the moisturizing container: 1 - cover, 2 - protective tubes, 3 - electrodes, 4 - thermometer, 5 - saturated solution of ammonium sulfate, 6 - plugs [17]

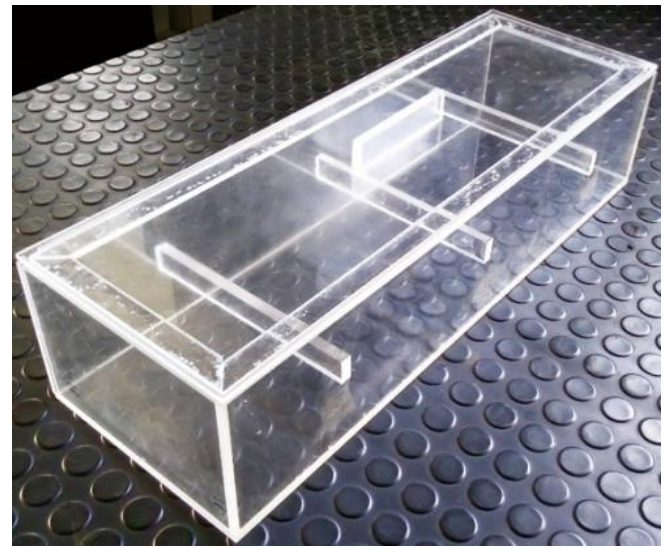

Fig. 5. Moisturizing container made of PMMA

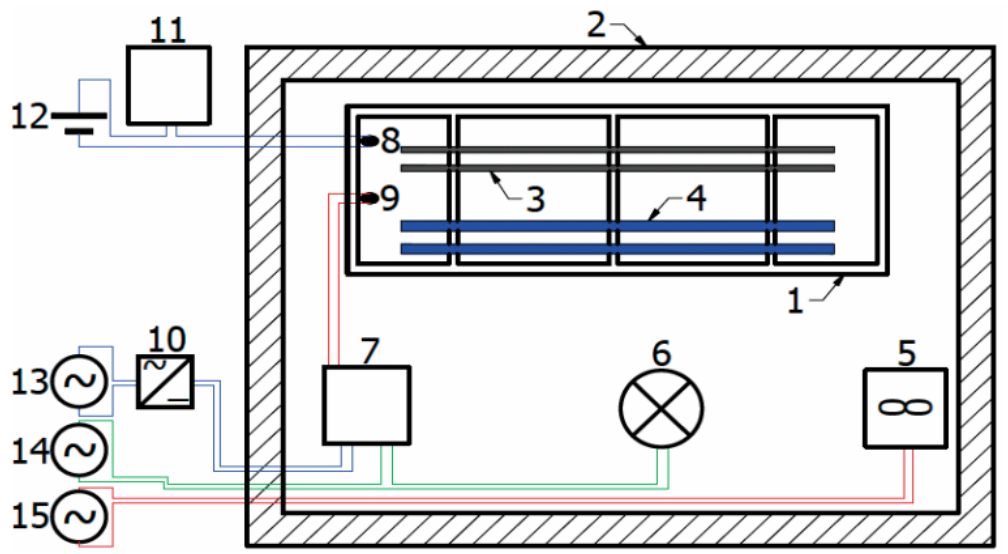

Fig. 6. Scheme of a temperature-controlled locker with moisturizing container: 1 - moisturizing container with a cover, 2 - thermal insulation locker, 3 - covered electrodes, 4 - protective tubes, 5 - ventilator, 6 - bulb, 7 - thermostat, 8 - thermometer sensor, 9 - thermostat sensor, 10 - rectifier, 11 - thermometer display, 12 - thermometer power supply, 13 - thermostat power supply, 14 - bulb power fan, 15 - fan power supply 
However, before this happens, a number of preparatory steps are required. The procedure foresees that you first prepare the moisturizing container by:

1. washing protective tubes in distilled water and drying them with compressed air;

2. sealing with plugs at one end of each pipe;

3. dissolving $1.3 \mathrm{~kg}$ of anhydrous ammonium sulfate solution in 1.5 liters of distilled water at a temperature of 40 to $45^{\circ} \mathrm{C}$;

4. filling the moisturizing container with a saturated ammonium sulfate solution to a level of $20 \div 25 \mathrm{~mm}$ (Fig. 4);

5. rubbing engine oil on the surface of the moisturizing container above the level of the chemical solution (to prevent crystallization of the solution);

6. allowing the solution inside the container to reach a temperature of $27 \pm 1^{\circ} \mathrm{C}$;

7. placing inside the container: protective pipes, plugs from the other end of the pipes (not inserted into the pipes), a thermometer and closing the lid.

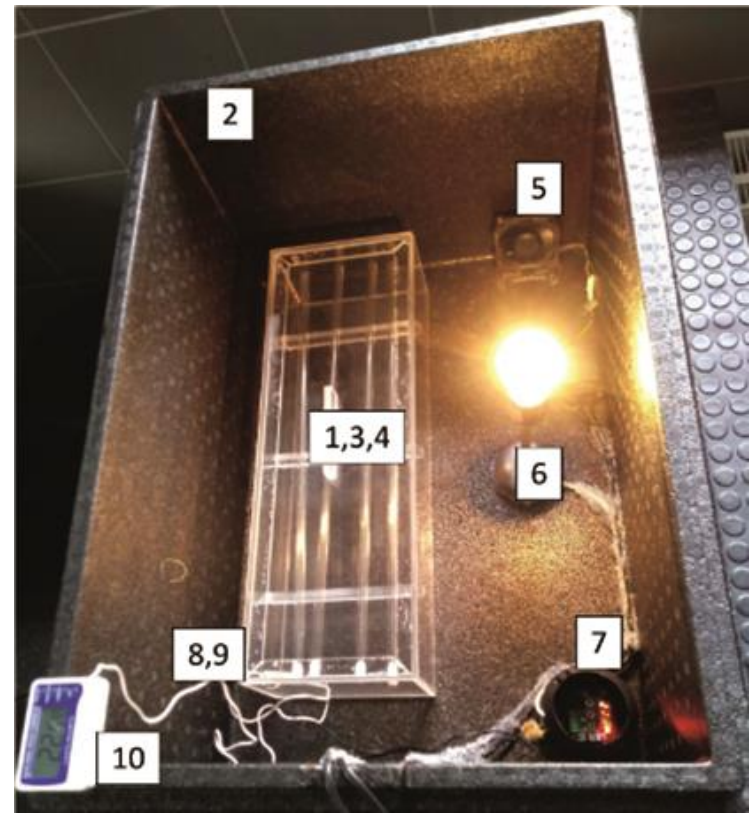

Fig. 7. Temperature-controlled locker with moisturizing container: 1 - moisturizing container with a cover, 2 - thermal insulation locker, 3 - covered electrodes, 4 - protective tubes, 5 - ventilator, 6 - bulb, 7 - thermostat, 8 - thermometer sensor, 9 - thermostat sensor, 10 - thermometer display

Then run the temperature-controlled locker by turning on the light bulb, fan and thermostat. The next step is to set the operating temperature on the thermostat $27 \pm 1^{\circ} \mathrm{C}$ and leave for 90 minutes to stabilize the temperature. After this time, place the sealed, previously prepared moisturizing container inside the locker for another 4 hours (maintaining the set operating temperature) and close the locker [27,28].

Then, to prepare the electrodes for humidification, they should be marked near the handle so that they can be identified. If the manufacturer requires pre-drying of the electrodes, this should be done in accordance with the instructions on the packaging. In the situation when the electrodes were dried at an elevated temperature, they should be closed in glass pipes, e.g. using tight-fitting rubber plugs, or placed in a desiccator to cool to room temperature $[27,28]$.

After these activities, the electrodes are exposed. In order to meet the standard, the cabinet and container should be opened within $90 \mathrm{~s}$, and then the electrodes should be placed in the moisturizing container as shown in Figure 4. After that, the container and the locker must be closed (these activities should be carried out within $30 \mathrm{~s}$ ) and left for 24 hours maintaining the temperature at $27 \pm 1^{\circ} \mathrm{C}[27,28]$.

Finally, activities related to the measurement of diffusible hydrogen are performed [28]:

- open a temperature-controlled locker;

- remove the cover from the moisturizing container. Insert the electrodes into the protective tubes and close with plugs (these operations should be carried out within $60 \mathrm{~s}$ );

- close the moisturizing container and temperature-controlled locker;

- move the electrodes in protective tubes to the welding station (the electrodes must be tested within 24 hours after removing them from the moisturizing container);

- note the ambient temperature and relative humidity during welding; 
- perform surfacing and determine of diffusible hydrogen content in deposited metal in accordance with PN-EN ISO 3690 Welding and related processes - Determination of hydrogen content in the weld metal [11,13]:

- make samples for surfacing (consisting of 3 plates: run-on, test and run-off from solid carbon steel, up to $0.18 \%$ carbon and up to $0.02 \%$ sulfur);

- mark test samples, degas, degrease the welded surface, weigh to the nearest $0.01 \mathrm{~g}$;

- mount the sample set on the welding stand (the stand should be at a temperature not higher than $25^{\circ} \mathrm{C}$ above room temperature);

- perform a padding weld;

- dismantle the sample set and cool immediately to stop hydrogen diffusion;

- remove slag as well as run-on and run-off elements;

- place the sample in a mercury burette (up to 2 minutes after welding);

- leave the sample for the duration of hydrogen evolution (14 days or $72 \mathrm{~h}$ if the measuring burette is kept at $45^{\circ} \mathrm{C}$ for the duration of the test);

- after the specified time, measure and record: the height of the hydrogen column, the difference between the levels of mercury in the arms of the tube, ambient temperature, atmospheric pressure and the mass of the sample with a padding weld;

- calculate the diffusible hydrogen amount in deposited metal or weld metal from the relationships given in the standard.

Depending on the impact of normalized humidification conditions on hydrogen amount in deposited metal, it can be classified as moisture resistant or with a standard cover.

The following information should be included in the test report:

1. Trade name of the electrode;

2. Electrode's marking;

3. Electrode's dimensions;

4. Details of the electrode's drying process (drying temperature and time);

5. Date and time of closing the exposure;

6. Date and time of welding start during the test;

7. Temperature range measured during exposure;

8. Measured duration of the exposure;

9. Information required according to PN-EN ISO 3690:

a. Date of performed measurements;

b. Name of the laboratory;

c. Name of the investigator;

d. Electrode's grade;

e. Lot number;

f. Welding current polarity;

g. Approximate release temperature;

h. Hydrogen collection time (days/hours);

i. Welding parameters (current, arc voltage, welding time, weld length);

j. Length of the used electrode;

k. Length of run-on;

1. Mass of weld metal on the test sample;

$\mathrm{m}$. Distance of the crater from the test sample;

n. Amount of diffusible hydrogen in the weld metal and molten material;

o. Other details not provided above.

10. Temperature and relative humidity of the air during welding.

\section{Results}

In order to verify the proper operation of the station, tests were carried out on two types of Lincoln Electric electrodes with a diameter of $4 \mathrm{~mm}$ [29]:

- OMNIA: ISO 2560-A: E 420 RC 11

- SHIELD-ARC HYP+: PN-EN 499: E 422 Mo C 25

Table I presents the chemical composition and properties of the weld metal from these electrodes [29]. OMNIA electrodes are general purpose rutile coated electrodes for welding in all positions, while SHIELDARC HYP+ are cellulose electrodes used to make transverse joints of transmission pipelines in a vertical 
positions (PG, PJ, J-L045). Welding with these electrode grades is one of the high-hydrogen processes. Four electrodes of each grade were used for the tests, two moistened in the station and two in the delivery condition. Humidification was carried out according to PN-EN ISO 14372 in accordance with the procedure described above. Then, according to PN-EN ISO 3690, diffusible hydrogen amount in deposited metal was determined using the mercury method. The results of the measurements are presented in tables II and III [28].

Table I. Characteristics of tested electrodes [29]

\begin{tabular}{|c|c|c|c|c|c|c|c|c|}
\hline \multirow{2}{*}{$\begin{array}{l}\text { Electrode } \\
\text { grade }\end{array}$} & \multirow{2}{*}{ Characteristic } & \multicolumn{3}{|c|}{$\begin{array}{l}\text { Approximate chemical } \\
\text { composition of the weld metal }\end{array}$} & \multicolumn{4}{|c|}{$\begin{array}{c}\text { Approximate mechanical properties } \\
\text { of the weld metal }\end{array}$} \\
\hline & & $\mathrm{C}[\%]$ & Mn [\%] & Si [\%] & $\begin{array}{c}\mathrm{Re} \\
{[\mathrm{MPa}]}\end{array}$ & $\begin{array}{c}\mathbf{R m}_{\mathrm{m}} \\
{[\mathrm{MPa}]}\end{array}$ & $\begin{array}{c}\text { A5 } \\
{[\%]}\end{array}$ & $\begin{array}{c}\mathrm{KCV} \\
{[\mathrm{J}]}\end{array}$ \\
\hline OMNIA & $\begin{array}{l}\text { Rutile-cellulose } \\
\text { covered electrode }\end{array}$ & 0.07 & 0.5 & 0.5 & 520 & 550 & 26 & $\begin{array}{c}60 \\
\left(0^{\circ} \mathrm{C}\right)\end{array}$ \\
\hline $\begin{array}{l}\text { SHIELD-ARC } \\
\text { HYP+ }\end{array}$ & $\begin{array}{l}\text { Cellulose covered } \\
\text { electrode }\end{array}$ & $0.13 \div 0.17$ & $0.49 \div 0.63$ & $0.08 \div 0.18$ & $435 \div 525$ & $525 \div 635$ & 24 & $\begin{array}{c}50 \\
\left(-29^{\circ} \mathrm{C}\right)\end{array}$ \\
\hline
\end{tabular}

Table II. Results of determination of the diffusible hydrogen content by the mercury method for electrodes in delivery condition [28]

\begin{tabular}{|c|c|c|c|c|c|c|}
\hline Name of the electrodes & $\mathbf{m}_{1}[\mathrm{~g}]$ & $\mathrm{m}_{2}[\mathrm{~g}]$ & $\mathbf{H}[\mathrm{mm}]$ & $\mathrm{C}[\mathrm{mm}]$ & $\mathrm{V}[\mathrm{ml}]$ & $\mathrm{HD}_{\mathrm{D}}[\mathrm{ml} / 100 \mathrm{~g}]$ \\
\hline OMNIA & 30.33 & 31.80 & 128.07 & 65.36 & 0.6574 & 44.42 \\
\hline OMNIA & 29.89 & 31.44 & 102.14 & 64.83 & 0.6784 & 43.65 \\
\hline SHIELD-ARC HYP+ & 30.75 & 32.31 & 89.26 & 69.36 & 0.7398 & 47.27 \\
\hline SHIELD-ARC HYP+ & 31.13 & 32.68 & 63.39 & 65.71 & 0.7275 & 46.70 \\
\hline
\end{tabular}

Table III. Results of determination of the diffusible hydrogen content by the mercury method for moisturized electrodes [28]

\begin{tabular}{|c|c|c|c|c|c|c|}
\hline Name of the electrodes & $m_{1}[g]$ & $\mathrm{m}_{2}[\mathrm{~g}]$ & $\mathbf{H}[\mathrm{mm}]$ & $\mathrm{C}[\mathrm{mm}]$ & $\mathrm{V}[\mathrm{ml}]$ & $\mathrm{HD}_{\mathrm{D}}[\mathrm{ml} / \mathbf{1 0 0 \mathrm { g } ]}$ \\
\hline OMNIA & 32.22 & 34.18 & 78.46 & 94.08 & 1.0254 & 52.32 \\
\hline OMNIA & 30.64 & 32.37 & 92.99 & 84.11 & 0.8976 & 51.89 \\
\hline SHIELD-ARC HYP+ & 29.43 & 31.13 & 68.70 & 97.75 & 1.0802 & 63.54 \\
\hline SHIELD-ARC HYP+ & 31.01 & 32.82 & 53.74 & 101.25 & 1.1425 & 63.12 \\
\hline
\end{tabular}

Based on the results obtained, it was found that the constructed, unique in the country, research test stand works as expected. Moisturizing two types of covered electrodes under standard conditions caused an 18\% (OMNIA) and 34\% (SHIELD-ARC HYP +) increase in the diffusible hydrogen content in deposited metal. Figure 8 shows the average measurement results. On their basis, the tested consumables for the group of electrodes with standard covering were classified [28].

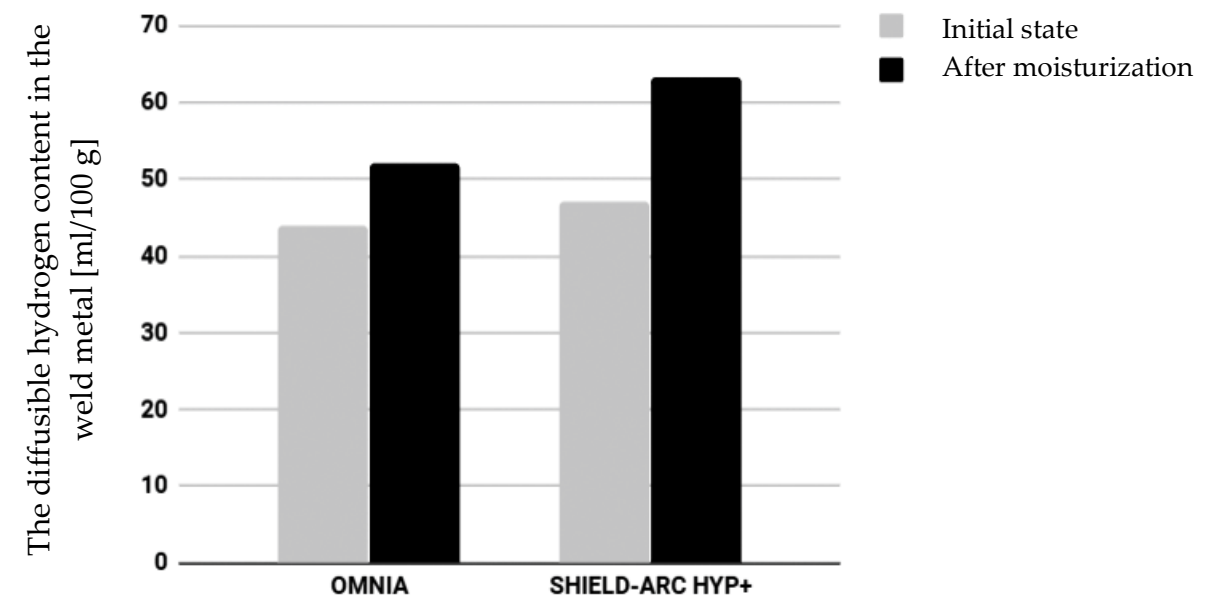

Fig. 8. The diffusible hydrogen content in tested samples 


\section{Summary}

The obtained results confirm the correct operation of the stand. It is a tool enabling determination of moisture resistance of electrodes for manual arc welding with covered electrodes and their classification into the group of electrodes with standard covering or resistant to moisture. It is probably the only container of this type in the country. Recently, it has also been modernized, improving the design to increase the accuracy of measurements.

Author Contributions: conceptualization K.M., A.W., D.F.; methodology A.W., A.Ś. and D.F.; investigation A.W, G.R. and D.F.; writing-original draft preparation K.M, A.W. and D.F.; writing-review and editing A.W., A.Ś., G.R. and D.F.; project administration A.W

Conflicts of Interest: The authors declare no conflict of interest.

\section{References}

[1] Reisgen U., Willms K., Wieland S., Influence of storage conditions on aluminum 4043A welding wires, Welding Journal, 2017, Vol. 96(6). [Hyperlink]

[2] Świerczyńska A., Effect of technological factors on diffusing hydrogen content in the weld deposit of rutile fluxcored wires, Institute of Welding Bulletin, 2013, Vol. 57(5). [Hyperlink]

[3] Harwig D.D., Longenecker D.P., Cruz J.H., Effects of welding parameters and electrode atmospheric exposure on the diffusible hydrogen content of gas flux cored arc welds, Welding Journal, 1999, Vol. 78(9). [Hyperlink]

[4] Schaupp T., Rhode M., Kannengiesser T., Influence of welding parameters on diffusible hydrogen content in highstrength steel welds using modified spray arc process, Welding in the World, 2018, Vol. 62(1).

[5] Chandan P., Mahapatra M.M., Kumar P., Saini N., Some studies on P91 steel and their weldments, Journal of Alloys and Compounds, 2018, Vol. 743.

[6] Fydrych D., Tomków J., Świerczyńska A., Determination of diffusible hydrogen content in the deposited metal of rutile electrodes by the glycerin method, Metallurgy and Foundry Engineering,2013, Vol. 39(1). [CrossRef]

[7] Fydrych D., Świerczyńska A., Landowski M., Preliminary studies of seamless flux cored wires stored in extreme conditions, Metallurgy and Foundry Engineering, 2016, Vol. 40(4). [CrossRef]

[8] Gürel C., İpekoğlu G., Recent developments in joining of aluminum alloys, The International Journal of Advanced Manufacturing Technology, 2017, Vol. 91(5-8)

[9] Fydrych D., Świerczyńska A., Tomków J., Diffusible hydrogen control in flux cored arc welding process, Key Engineering Materials, 2014, 597. [CorssRef]

[10] Tomków J., Fydrych D., Rogalski G., Łabanowski J., Effect of the welding environment and storage time of electrodes on the diffusible hydrogen content in deposited metal, Revista de Metalurgia, 2019, 55, e140. [CrossRef]

[11] Fydrych D., Łabanowski J., Determining diffusible hydrogen amounts using the mercury method, Welding International, 2012, Vol. 26(9). [CrossRef]

[12] Kiefer J.H., Effects of moisture contamination and welding parameters on diffusible hydrogen, Welding Journal, 1996, Vol. 75(5). [CrossRef]

[13] Fydrych D., Łabanowski J., An experimental study of high-hydrogen welding processes, Revista de Metalurgia, 2015, Vol. 51(4). [CrossRef]

[14] Bracarense A.Q., Souza R, Costa M.C.M., Faria P.E., Liu S., Welding current effect on diffusible hydrogen content in flux cored arc weld metal, Journal of the Brazilian Society of Mechanical Sciences 2002, Vol. 24(4). [CrossRef]

[15] Maria G.G.B., Claeys L., Depover T., Santos D.B., Verbeken K., The hydrogen induced mechanical degradation of duplex stainless steel, Steel Research International, 2019, Vol. 90(1). [CrossRef]

[16] Claeys L., Depover T, De Graeve I., Verbeken K., Electrochemical hydrogen charging of duplex stainless steel, Corrosion, 2018, Vol. 75(8). [CrossRef]

[17] Liu Q., Zhou Q., Venezuela J., Zhang M., Atrens A., Evaluation of the influence of hydrogen on some commercial DP, Q\&P and TWIP advanced high-strength steels during automobile service, Engineering Failure Analysis, 2018, Vol. 94. [CrossRef]

[18] Ohaeri E., Eduok U., Szpunar J., Hydrogen related degradation in pipeline steel: A review, International Journal of Hydrogen Energy, 2018, Vol. 43(31).[CrossRef]

[19] Padhy G.K., Ramasubbu V., Albert S.K., Murugesan N., Ramesh C., Hot extraction of diffusible hydrogen and its measurement using a hydrogen sensor, Welding in the World, 2012, Vol. 56(7). [CrossRef]

[20] Łomozik M., Metaloznawstwo i spawalność metali, Materiały szkoleniowe Instytutu Spawalnictwa w Gliwicach, Gliwice 1997. 
[21] Kotecki D.J., Hydrogen reconsidered, Welding Journal, 1992, Vol. 71(8).

[22] Ramirez J.E., Johnson M., Effect of welding parameters and electrode condition on alloying enrichment of weld metal deposited with coated cellulosic electrodes, Welding Journal, 2010, Vol. 89(11). [Hyperlink]

[23] Pakos R., Właściwości złączy spawanych wykonanych elektrodami zasadowymi i celulozowymi, Welding Technology Review, 2011, Vol. 38(5). [CrossRef]

[24] Felber S., Mechanical-technological and fracture mechanical properties of the high grade pipeline-steel X80 with results of different pipeline-projects, Welding in the World, 2008, Vol. 52(5-6). [CrossRef]

[25] Felber S., Welding of the high grade pipeline-steel X80 and description of different pipeline-projects, Welding in the World, 2008, Vol. 52(5-6). [CrossRef]

[26] Łędzki A., Michaliszyn A., Klimczyk A., Metalurgia ekstrakcyjna żelaza /do użytku wewnętrznego AGH/

[27] Wciseł J., Budowa stanowiska do nawilżania elektrod otulonych zgodnie z normą PN EN ISO 14372:2005, Projekt inżynierski wykonany pod opieką dr. hab. inż. G. Rogalskiego, Politechnika Gdańska 2018.

[28] Wolski A., Badania nasiąkliwości elektrod otulonych, Projekt inżynierski wykonany pod opieką dr. hab. inż. G. Rogalskiego, Politechnika Gdańska 2018.

[29] Welding consumables. Catalog. Lincoln Electric, 2017.

(C) 2019 by the authors. Submitted for possible open access publication under the terms and conditions of the Creative Commons Attribution (CC BY) license (http://creativecommons.org/licenses/by/4.0/). 